\title{
Application of Criminal Sanctions Against The Crime of Child Rape Linked with Article 82 of Act No. 35 of 2014 Concerning The Protection of Children
}

\author{
Ervin Faizal Nurdiansyah ${ }^{1}$
}

Abstract. This study aimed to analyze the application of criminal sanctions against child rape. Legal issues that arise in this research include: How the application of criminal sanctions against criminal fines rape of children in the jurisdiction of Polresta Cirebon, and How the effectiveness of the application of criminal sanctions against perpetrators of child rape fines in Polresta Cirebon Jurisdiction. This research is a normative law and empirical legal research based on the consideration that in addition to leaving of the Act, the researchers also explored what is in the field related to the title of the researchers adopted, it can be concluded that the application of criminal sanctions penalties against perpetrators of criminal acts of rape of children Polresta Cirebon Jurisdiction in accordance with article 82, paragraph (1) and (2) of Act No. 35 of 2014 on Child Protection that the penalties are imprisonment of at least five (5) years and a maximum of 15 (fifteen)

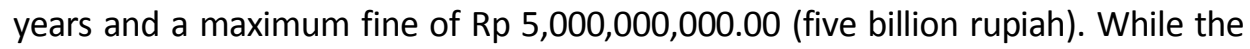
effectiveness of the application of criminal sanctions against child rape because the victim has not been effective enough that the injured party did not receive material compensation to pay for treatment and rehabilitation. For offenders, penalties are less able to provide a deterrent effect because the perpetrators are not able to pay these fines can be replaced with imprisonment for a long time very briefly. While the effectiveness of the application of criminal sanctions against child rape because the victim has not been effective enough that the injured party did not receive material compensation to pay for treatment and rehabilitation. For offenders, penalties are less able to provide a deterrent effect because the perpetrators are not able to pay these fines can be replaced with imprisonment for a long time very briefly. While the effectiveness of the application of criminal sanctions against child rape because the victim has not been effective enough that the injured party did not receive material compensation to pay for treatment and rehabilitation. For offenders, penalties are less able to provide a deterrent effect because the perpetrators are not able to pay these fines can be replaced with imprisonment for a long time very briefly.

Keywords: Criminal sanctions; Child Rape; Child Protection.

\section{Introduction}

In the Constitution of the Republic of Indonesia Of 1945 Article 1 (3) explained that Indonesia is a State of Law. Under these conditions, the Indonesian State upholds and respects one of the pillars of the rule of law, namely the protection and respect of human rights as contained in the Constitution of the Republic of Indonesia Of 1945 Article 27 paragraph (1) which states that "All Citizens are equal before the law and government and shall uphold the law and the government, without exception ".

Fines are the oldest form of criminal older than imprisonment may be as old as the death penalty, although its form is primitive because since the time of Majapahit to some primitive and traditional societies recognize criminal penalties.

\footnotetext{
${ }^{1}$ Student of Master of Law, Universitas Islam Sultan Agung Semarang and Police Members Officer ervin.fn88@gmail.com
} 
The judiciary has an important role in ensuring the protection of the rights of children, both children as perpetrators or as victims children. Judge as an officer who has wewenanag in check and give the verdict for criminal acts in particular cases of rape of minors, must provide firm decision and can satisfy the justice for society in general and the rights of children who are victims in particular. Legal protection for children not only in terms of protecting children Indonesia or juridical, but need a broader approach, namely economic, social and cultural rights.

For victims of child rape, to return to the community with this fair who are not covered by the Law on Child Protection for child victims of rape could be stress, trauma, shame lifetime and feel excluded from society children of his age. To restore this required rehabilitation costs of trauma in particular, the physical treatment and other costs in order to sustain the learning for children who are still in school in a way moved his school, it certainly carries a cost, it has been duly borne by the offender by way of convicted penalties and fines are paid to the state that can be used as the cost of rehabilitation of victims.

Based on the background of the above authors in this study are interested to take title, Application of Criminal Sanctions Against The Crime of Child Rape Linked With Article 82 of Act No. 35 of 2014 Concerning The Protection of Children". With more directed at the facts (empirical) that occur in the field for analysis.

Based on the description above, narrowed some of the questions in this study are: How the application of criminal sanctions against criminal fines rape? What is the effectiveness of criminal sanctions criminal fines against rape?

\section{Research methods}

The research is a normative legal research that focuses on legal norms applicable legal norms and assessment is done by examining the secondary data as the main data, while the primary data as a supporter. Data sources include secondary data in this study come from: 1) Material Primary Law, ie substances that bind and positive law consists of legislation: 1. The Constitution of the Republic of Indonesia Of 1945. 2. Act No. 35 of 2014 on Child Protection; 2) Secondary Legal Materials, the material used to provide a description of the primary legal materials and consists of literature which contains the opinions of law.

Data was collected by means of: 1) literature study, done by studying, read and understand the books, legislation and pendapatpendapat which is closely related to the matter being investigated. 2) The interview, conducted by asking questions to the resource persons directly face to face. Authors prepare questions that will be posed to the resource persons. Guest speaker is Ms. Ipda Suwarni, who served as head of Women and Children Protection Unit Polresta Cirebon (Chief of Unit PPA)

The data obtained from these studies were processed and analyzed by descriptive qualitative, that all the data was analyzed intact so it looks the picture of systematic and factual. Once analyzed, the authors draw conclusions using deductive method of thinking, which is a pattern of thinking that is based on matters of a general nature and then drawn the conclusion of a special nature.

\section{The Results and Discussion}

\subsection{Application of Criminal Penalties Sanctions Against Crime Perpetrators of Child Rape}


In this modern age, criminal fines has undergone many changes. Since the formation of the Act No. 1 in 1946 to encourage the creation of new crimes outside the Criminal Code by using fines to criminal sanctions as a means to strengthen the criminal enactment of new rules in anticipation of the growing criminality (new crimes).

The increasing use of criminal sanctions fines as mentioned above, many experts view as a natural thing, because society is constantly evolving, developing new legislation to meet the needs of the community. As said by Ruslan Saleh, that criminal law reflects its time and depend on the thoughts of living in society, be it regarding the shape crime, also the light weight of punishment. ${ }^{2}$ And history shows that change and the development of crime followed by changing and growing crime itself. ${ }^{3}$ The same view was stated by $\mathrm{S}$. Balakrishnan, that "criminal law was changed and should require a change in accordance with changes in society. Not only about what conduct is declared or defined as a crime, but also about what should be used as punishment for a crime, because notions of criminal has also changed in accordance with the changes, especially in view of moral and civic life. ${ }^{4}$

Fines have many drawbacks and advantages, as well as imprisonment. But regardless of the weaknesses and advantages that exist, fined unbelievably needed. Fines expected to be a cornerstone of the motivation for legislative policy to further improve the functioning of the criminal penalties as a means of punishment both in his capacity as the types of sanctions that stand alone (independent sanction) as well as the type of criminal punishment alternative to imprisonment for short term as well as a deep understanding of the weaknesses / power limitations for criminal penalties, is expected to be a feedback signal at a time that should be considered to deal with the operational policy strategy to better serve criminal fines or to work more effectively in reality.

Rape is an attempt sexual lust by a man against a woman in a way that moral or violate any applicable laws. ${ }^{5}$ The types of rape are:

- Sadistic Rape, meaning of sexuality in the form of the damage.

- Anger Rape, meaning sexual abuse

- Domination Rape, meaning that the perpetrator tried to-powered and superiority over the victim.

- Seductive Rape, meaning that rape occurs in situations that stimulate both sides.

- Victim Precipitated Rape, meaning that a rape had occurred because the victim as originators.

- Exploitation Rape, rape taking advantage of the victim with the position of the position of women who rely on them economically and socially. ${ }^{6}$

According to Arif Gosita, the rape victim is a woman, who by force or by threat of violence forced sexual intercourse with another person outside marriage. ${ }^{7}$

\footnotetext{
${ }^{2}$ Saleh Roeslan 2003 Hukum Pidana sebagai Konfrontasi Manusia dan Manusia Ghalia Indonesia Jakarta p. 3

${ }^{3}$ Muladi and Barda Nawawi Arief Teori-Teori Hukum p. 88

${ }^{4}$ Ibid p.89

${ }^{5}$ Suparman Marzuki (et.al) Pelecehan Seksual (Yogyakarta Fakultas Hukum Universitas Islam Indonesia 1997) p. 25

${ }^{6}$ Abdul Wahid dan Muhammad Irfan Op Cit p. 46-47

${ }^{7}$ Arif Gosita Relevansi Viktimologi Dengan Pelayanan Terhadap Para Korban Perkosaan (Some Notes) (Jakarta IND.HILL-CO 1987) p. 12
} 
Phasing the suffering of victims of crime of rape can be divided as follows ${ }^{8}$ :

- Before the Court of Justice. The crime of rape victims suffer mental, physical and social because he tried to tell the police ill and mentally disturbed. Then to collect data for evidence of the crime of rape, he should tell the events that cause trauma to the police. Victims also fear the offender threat due to report so there will be retaliation against him.

- During the Court Session. The crime of rape victims must be present in court proceedings on their own costs to be a witness. Repeating the story of bitter experience and make reconstruction of the events of rape and faced with the actors who've raped once people hated. It is not uncommon that victims face criminal rape is more capable mentally, physically, socially rather than himself. Here it turns out necessary to provide a companion or advocates for the victims of the crime of rape.

- After the Court of Justice. After completion of the trial, the crime of rape victims still face numerous difficulties, especially not receive compensation from anyone. Health maintenance remain dependents. He remains seized with the fear of threats from the perpetrators. There is a chance he is not accepted into the family and the environment as they are, because he has a disability.

It is very necessary for the protection of the victims of rape by the state in accordance with applicable regulations. Perlindngan was conducted during the investigation period of the trial and after the trial. It takes also assistance and recovery of victims physically and psychologically.

Based on the systematics of the Criminal Code, the classification of the offenses consist of: Crime (Misdrijven) in Book II, Section 104-488; and Abuse (Overtredingen) in Book III, Section 489-569.

However, not explained what the basic policy of the manufacturer of the Criminal Code (WvS) to classify an act as a crime or a violation. According Romly Atmasasmita, classification or differentiation of criminal offenses such as 'crime' (Misdrijven) and offense (Overtredingen) is derived from the difference between mala in se and malum prohibitum known in Greek law. Mala in se is an act that is referred to as a crime because of a nature of evil. Medium malum prohibitum, an act called the crime because the law set as a prohibited act. The distinction between crimes and violations were originally based on the consideration of their understanding of the term rechtsdelict and wetsdelict ${ }^{9}$, Rechtdelict (Prosecutions) means that without legislation, without the judge's decision was perceived by the public as an offense (crime); while wetsdelict (offense legislation) means that it is the law that establishes an offense included offense ${ }^{10}$

Pengancaman policy amount (magnitude) of the Criminal Code apply criminal penalties in the formulation 'common minimum' (Algemene minima) and 'specific maximum (maxima speciale)'. Common minimum criminal penalties, under Article 30 paragraph (1) is set at Rp 25 cents. While the particular maximum determined individually in the formulation of the offense contained in Books II and III with varying amounts.

In line with the development of the value of money in the community, where the number of threats of criminal penalties deemed no longer appropriate because it is too mild / mild

\footnotetext{
${ }^{8}$ Ibid. p.17-20

9 Romly Atmasasmita Perbandingan Hukum Pidana Mandar Maju Bandung 1996 p.49

${ }^{10}$ Andi Hamzah Hukum Pidana Ekonomi (Revision Edition as Inpres No. 4 of 1985) Erlangga Jakarta 1996 p. 36
} 
then issued several regulations that have an impact on changes to the criminal sanctions (fines), namely: Article 82 paragraph (1) and (2) of Act No. 35 of 2014 on Child Protection that the penalties are imprisonment of at least five (5) years and a maximum of 15

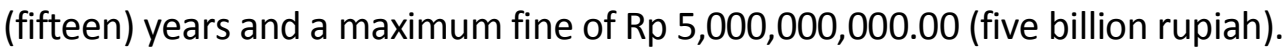

\subsection{Effectiveness of Criminal Sanctions Child Rape Crime Penalties}

Development to expand the use of criminal penalties by increasing the amount of penalty of fines alone was not sufficient to improve the effectiveness of criminal fines. It requires a comprehensive policy in the legislative, judicial, or executive. According Muladi and Barda Nawawi Arief, in the execution of criminal penalties should be considered among others: a. System application number or the magnitude of the criminal. b. Implementation deadline of payment of fines. c. Acts of coercion that is expected to guarantee the implementation of the payment of fines in the case of the convicted person can not pay within the time limit set. d. Implementation of the criminal in specific things (eg, to a minor child or has not worked and is still in a dependent parent). e. Guidelines or criteria to impose criminal penalties. Criminal fines property object is a form of money, this can be seen in the provisions of the Criminal Code.

Based on the assessment report on the application of criminal law penalties Dep.Kes.RI, it turns out that criminal penalties have so far felt not fulfill the purpose of punishment, due to the following factors: the implementation of the fines to his predecessor by not the perpetrator, causing a sense of dipidananya perpetrators be lost. Values penalty of fines in feel too too low, so it does not correspond to the alignment between the objectives of punishment with a sense of justice in society. Despite the high criminal threat in criminal rule out the Criminal Code, but has not been able to follow the rapid development of currency values in society.

However, irrespective of the above, the type of penalty Gives many Facets of justice, among others: Payment of fines is easy to implement and can be revised if there is a mistake, Compared with other types of punishment. Fines favorable government for not much cost, if without the confinement subsidiary. But fines are not brought or did not lead to deplorable reputation or honor like that of the convict prison. A financial penalty will be income for the region or city. A review of the pattern of criminal penalties in criminal law and in Indonesian RKUHP positive.

To see how the position and pattern of criminal penalties in criminal law positively Indonesia, then first of all we departed from the provisions of article 10 of the Criminal Code, the which states that: Criminal staple, consisting of: Criminal death, Imprisonment, Imprisonment, criminal fines, and criminal Coverage (added by Act No. 20 of 1946). Additional penalty, consisting of: deprivation of certain rights, deprivation of certain items and the announcement of the judge's decision.

Penal Code system does not recognize the general maximum limit penalty, but only a specific maximum limit in the Articles. On the contrary in the Criminal Code prescribed general minimum limit penalty, amounting to twenty-five cents (250,-). When traced the highest number of criminal penalties in the Criminal Code is $\mathrm{Rp} \mathrm{150,000,} \mathrm{-} \mathrm{a} \mathrm{man}$ threatened in articles 251 and 403, while for the offense (Book III) criminal fine of Rp 75,000, - contained in articles 568 and 569.

\section{Closing}




\subsection{Conclusion}

From the discussion above may take the conclusion that:

- Criminal sanctions are criminal penalties against child rape in accordance with article 82, paragraph (1) and (2) of Act No. 35 of 2014 on Child Protection that the penalties are Imprisonment of at least five (5) years and a maximum of 15 (fifteen) years and a

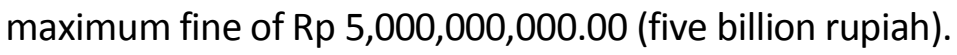

- Criminal sanctions are fines was not yet Able to Make the perpetrators of criminal acts of rape was a deterrent, Because if the Offender can not pay the fine darpat replaced with Imprisonment for the duration of just a few months.

- Child rape Victims do not feel protected by the Law on child protection, due to the fact that fines given to countries not to help the victims of his life in the future.

\subsection{Suggestion}

The advice can be delivered in this paper is that the government in this regard through the tools that have been given the authority of the police, prosecutors, judges and lawyers to be more active in preventing and combating all forms of crime / violence, especially against children child. In addition to the role of the community determine the success of justice for children who have been victims of violence in both the internal and external environment. Therefore, the socialization of the child protection law is implemented thoroughly in order to be informed, and ultimately have a high awareness of the law.

\section{References}

[1] Amiruddin 2012 Pengantar Metode Penelitian Hukum PT Raja Grafindo Persada Jakarta.

[2] Gosita Arief 2003 Masalah Korban Kejahatan Akademika Pressindo Jakarta.

[3] 2009 Masalah Perlindungan Anak Akademi Pressindo Jakarta.

[4] Hakim G Abdul 2006 Hukum dan Hak-Hak Anak Rajawali Jakarta.

[5] Hamzah Andi 2003 Suatu Tinjauan Ringkas Sistem Pemidanaan Indonesia Akademika Presindo Bandung.

[6] Hamzah Andi 2003 Suatu Tinjauan Ringkas Sistem Pemidanaan di Indonesia Akademika Presindo Jakarta.

[7] Mardjono Reksodiputro 2009 Pembaharuan Hukum Pidana Pusat Pelayanan Keadilan Hukum Jakarta.

[8] M Sidabalok Hosiana 2012 Perlindungan Hukum Terhadap Anak sebagai Korban pemerkosaan Jakarta.

[9] Saleh Roeslan 2003 Hukum Pidana sebagai Konfrontasi Manusia dan Manusia Ghalia Indonesia Jakarta.

[10] Siregar Bismar 2006 Keadilan Hukum dalam Berbagai Aspek Hukum Nasional Rajawali Jakarta.

[11] Soerjono Soekanto 2011 Faktor - faktor yang Mempengaruhi Penegakan Hukum PT Raja Garfindo Persada Jakarta.

[12] 2011 Penelitian Hukum Normatif Jakarta : PT RajaGrafindo Persada.

[13] Soerodibroto R. Soenarto 2006 KUHP dan KUHAP: Dilengkapi dengan Yurisprudensi Mahkamah Agung dan Hoge Raad Raja Grafindo Persata Jakarta. 